УДК $351: 328.18]:[316.77$

https://doi.org/10.52058/2708-7530-2021-9(15)-66-75

Горбатюк Петро Михайлович аспірант кафедр глобальної та національно безпеки ННІ Публічного управління та державної служби? КНУ імені Тараса Шевченка, вул. Антона Цедіка, 20, м. Київ, 03057, тел.: (067) 382-62-88, e-mail: petia.gorbatiuk@gmail.com, https://orcid.org/0000-0002-8383-5796

\title{
ІНФОРМАЦІЙНА СКЛАДОВА ВЗАЕМОДІЇ ОРГАНІВ ПУБЛІЧНОГО УПРАВЛІННЯ 3 ГРОМАДСЬКІСТЮ У ПРОЦЕСІ ПРИЙНЯТТЯ РІШЕНЬ
}

Анотація. У статті досліджено різні аспекти використання інформаційних механізмів взаємодії органів публічного управління з громадськістю у процесі прийняття рішень

У статті наголошується що громадська участь передбачає активну участь громадян при відстоюванні своїх прав та інтересів в процесі прийняття рішень, а також вибір і використання різних методів участі. Залучення громадськості передбачає проактівні дію з боку осіб, які приймають рішення, з обрахування вміння громадян щодо рішень, що приймає влада. Характеризуються різні форми вибору правильного рівня участі громадськості, переваги такого вибору та :

Зазначається, що в основі кожного процесу участі громадськості лежить обіцянка, дана владою громадськості. Ця обіцянка представляє те, що громадськість може очікувати від органу публічної влади щодо доступу до потенційного впливу на вирішення проблеми. Обіцянка також визначає очікуваний рівень інформації і спілкування. Описуються фактори, які повинні бути покладі у основу таких обіцянок громадськості. У статті аналізуються способи, завдяки яким можна підвищити потенціалу участі громадськості у процесах прийняття рішень. Серед додаткових факторів, які необхідно враховувати для успішної участі громадськості у статті називається прозорість, що являє собою готовність органів публічної влади в повній мірі ділитися інформацією, критеріями і обговореннями процесу прийняття рішень з громадськістю.

Доводиться, що участь громадськості у процесах прийняття управлінських рішень розвиває потенціал спільноти, що це є ще одним важливим результатом постійної участі зацікавлених сторін у прийнятті рішень і їх реалізації. Це також $\epsilon$ розвиток здатності вирішувати складні соціальні проблеми.

Робиться висновок проте, що у демократичній державі забезпечення прозорості системи державного управління є однією з ключових, невід'ємних складових державної інформаційної політики, стратегічна мета якої полягає в побудові відкритого інформаційного суспільства.

Ключові слова: взаємодія, публічна влада, інформаційні механізми, громадськість. 
Gorbatiuk Petro Mikhailovich Graduate student of the Departments of Global and National Security, Institute of Public Administration and Civil Service of Taras Shevchenko National University, Anton Tsedik St., 20, Kyiv, 03057, tel.: (067) 382-6288, e-mail: petia.gorbatiuk@gmail.com, https://orcid.org/0000-0002-8383-5796

\title{
INFORMATION COMPONENT OF INTERACTION OF PUBLIC GOVERNMENT BODIES WITH THE PUBLIC IN THE DECISION-MAKING PROCESS
}

\begin{abstract}
The article investigates various aspects of the use of information mechanisms of interaction of public administration bodies with the public in the decision-making process.

The article emphasizes that public participation involves the active participation of citizens in defending their rights and interests in the decision-making process, as well as the choice and use of various methods of participation. Involvement of the public involves proactive action by decision-makers, taking into account the ability of citizens to make decisions by the authorities. Various forms of choosing the right level of public participation, the benefits of such a choice and:

It is noted that at the heart of every process of public participation is a promise made by the public authorities. This promise represents what the public can expect from a public authority to have access to potential influence on the problem. The promise also determines the expected level of information and communication. The factors that should underlie such public promises are described. The article analyzes the ways in which it is possible to increase the potential of public participation in decisionmaking processes. Additional factors that need to be considered for successful public participation in the article are transparency, which is the willingness of public authorities to fully share information, criteria and discussions in the decision-making process with the public.
\end{abstract}

It is argued that public participation in management decision-making processes develops the potential of the community, which is another important result of the ongoing participation of stakeholders in decision-making and implementation. It is also the development of the ability to solve complex social problems.

It is concluded, however, that in a democracy, ensuring the transparency of public administration is one of the key, integral components of public information policy, the strategic goal of which is to build an open information society.

Keywords: interaction, public power, information mechanisms, public.

Постановка проблеми. Практики взаємодії суспільства і влади як правило проявляються через соціальні форми і механізми громадської участі, вони формують смислове поле категорії «громадянське суспільство». У центрі дієвих практик, що характеризують сучасне громадянське суспільство, виявляються нові суб'єкти впливу і простору позиціонування їх соціальних зв'язків (в тому числі, 
соціального капіталу). У вітчизняній i зарубіжній науці в останні роки обгрунтовується необхідність пошуку якісно нових підходів, що дозволяють пояснити поведінку соціальних суб'єктів і природу громадської участі. 3 часом змінюються уявлення про типи і форми взаємозв'язку і взаємозалежності держави і суспільства. На рубежі XX-XXI ст. сформувалися стійкі моделі взаємодії механізмів державного і громадського контролю, з'явилися нові технології державно-приватного партнерства, що відображають необхідність в управлінні та регулюванні соціального розвитку, які з нових позицій висвітлили проблеми розвитку громадянського суспільства. 3 розвитком держави потреба у формуванні громадянського суспільства і підвищення ролі його інститутів буде зростати, актуалізувалася наукова проблема в розробці нової теорії громадянського суспільства. Про це свідчить сучасна тенденція до посилення громадянського дискурсу з вивчення інституту громадського контролю.

Громадська участь передбачає активну участь громадян при відстоюванні своїх прав та інтересів в процесі прийняття рішень, а також вибір і використання різних методів участі. Залучення громадськості передбачає проактівні дії з боку осіб, які приймають рішення, з обрахування вміння громадян щодо рішень, що приймає влада. Члени місцевої громади не завжди можуть знати про розробку програм або рішень, які зачіпають їх інтереси, а особи, які приймають рішення, не завжди можуть володіти вичерпаної інформацією щодо проблем, які готується для обговорення та голосування по ним. Завданням залучення громадськості стає прийняття продуктивних рішень, здатних ефективно використовувати наявні суспільні ресурси, наприклад таки, як бюджет органів місцевого самоврядування[1]. Перевага залучення громадськості в діалоги на місцевому рівні полягає в кращому експертному знані членів місцевої громади про потреби регіону, а також в зростання довіри до прийнятих рішень керівниками органів публічної влади та органів місцевого самоврядування. Для того щоб залучення громадськості відбулося, таким керівникам необхідно вжити ряд зусиль по організації врахування думки місцевої громади, що включає всіх зацікавлених груп.

Аналіз останніх досліджень і публікацій. Проблематика взаємодії органів публічної влади з громадянськістю є предметом наукових пошуків як зарубіжних так й вітчизняних вчених вже протягом тривалого часу. В Україні ця тема набуває розвитку та стає предметом наукового дискурсу з 90-х років ХХ століття, але до сьогодення залишається дискусійною. Серед зарубіжних учених, які досліджують механізм взаємодії місцевої влади з громадянським суспільством, можна виділити Н. Алфасі, Н. Борджелі, В. Брайт, У. Камерон, Дж. Ван дер Мір, А. Едвардс, О. Смолянко, Ю. Хабермаса тощо. Серед українських науковців вивченням даної проблематики займаються Т. Андрійчук, А. Буханевич, А. Дідух, О. Самбук, Л. Усач, О.Пухкал, Ундір В. О Кармазіна О.О., І Ковбас, I. Торончук, П. Крайній та ін.

Аналіз історіографії проблеми взаємодії органів публічної влади 3 
громадськістю у вітчизняній та зарубіжній науці дозволяє дійти висновку, що механізми такої взаємодії потребують наукового дослідження та актуалізації.

Проведений аналіз також свідчить, що більшість досліджень такої взаємодії присвячені різним механізмам, але проблеми застосування інформаційних механізмів такої взаємодії не $є$ достатньо дослідженими. Тож відсутність системних досліджень зазначеної проблематики, незважаючи на іiі виняткове значення для забезпечення стійкості суспільства та держави, зумовлюють необхідність проведення нашого дослідження.

Мета статті. Автор статті ставить за мету дослідити інформаційну складову взаємодії органів публічного управління з громадськістю у процесі прийняття рішень.

Виклад основного матеріалу. Участь громадськості у процесі прийняття рішення - це процес іï внеску у суспільний порядок та соціальну стійкість громади. Участь громадськості дає зацікавленим сторонам (тим, хто зацікавлений у вирішенні будь-якої проблеми, наприклад, окремим особам, групам інтересів, співтовариствам) можливість впливати на рішення, що впливають на якість їхнього життя.

Чиновники органів публічної влади не повинні сприймати отриману інформацію у вигляді громадської думки як необхідність робити «те, що громадськість хоче». Зазвичай, немає єдиної громадської думки. Швидше, громадськість складається з ряду зацікавлених сторін, які дотримуються різних поглядів i побоювань 3 того чи іншого суспільно значущого питання. При здійсненні громадянської участі орган публічної влади буде збирати інформацію 3 широкого спектру інтересів зацікавлених сторін, в результаті чого виробляється широкий спектр поглядів і проблем і забезпечується рівне та справедливе ставлення, спільна участь і соціальна інтеграція для всіх членів громади, незалежно від раси, кольору шкіри, національного походження, сексуальна орієнтація або доходу, щодо розробки, реалізації рішень, що прийняті в процесі участі громадськості. У такому випадку робота державних службовців полягає в тому, щоб знайти баланс між цими поглядами і проблемами.

Сам процес участі громадськості у прийнятті управлінських рішень не $\epsilon$ однаковим. Здійснення значимої участі громадськості передбачає пошук думок громадськості на різних конкретних етапах процесу прийняття рішень і 3 конкретних питань, де такий внесок може реально допомогти у формуванні рішення або здійснення управлінської дії. Просто запитати громадськість «чого ви хочете» не завжди буває доречним або корисним. Такі загальні питання тільки викличуть велике очікування i, можуть нашкодити у тих сферах суспільного життя, де вплив громадськості може бути обмеженим, наприклад, у сфері національної безпеки. В той час як в інших сферах вплив громадськість може мати велике позитивне значення. Величина цього потенційного впливу $€$ основним фактором при розробці успішної програми участі громадськості.

Вибір правильного рівня участі громадськості включає різні форми, які може 
приймати участь громадськості в залежності від потенціалу громадського впливу на рішення. Ці форми включають[2]:

інформування громадськості шляхом надання інформації, яка допоможе їм зрозуміти проблему та варіанти іiі рішення;

консультації з громадськістю для отримання іiі відгуків про альтернативні варіанти рішення проблеми;

залучення громадськості для забезпечення того, щоб їх проблеми враховувалися протягом всього процесу прийняття рішень, особливо при розробці критеріїв і варіантів рішення;

співпраця 3 громадськістю для розробки критеріїв прийняття рішень та альтернативних рішень і визначення кращого рішення;

розширення прав і можливостей громадськості у прийнятті рішень.

Залежно від бажаної форми участі громадськості у прийнятті рішень використовуються різні інструменти і методи для інформування громадськості, створення громадської думки i, в деяких випадках, досягнення консенсусу i згоди.

Участь громадськості - це не просто вимога часу або популізм, це необхідна частина досягнення суспільної згоди та дія, яка призводить до ефективної взаємодії між народом та владою та т.зв. good governance. При осмисленому підході участь громадськості може призвести до двох значних переваг:

органи публічної влади будуть приймати більш якісні і легко реалізовані управлінські рішення, які відображають суспільні інтереси і цінності і краще розуміються громадськістю;

органи публічної влади розвивають довгострокову здатність вирішувати складні соціальні проблеми, часто долаючи давні розбіжності і непорозуміння.

Участь громадськості сприяє прийняттю більш ефективних рішень, оскільки особи, які приймають рішення, мають більш повну інформацію - у формі додаткових фактів, цінностей і точок зору, отриманих в результаті участі громадськості, все це вони використовують в процесі прийняття рішень. Вони також можуть використовувати великий масив інформації, отриманий у процесі взаємодії з громадськістю і знати бажання усіх зацікавлених сторін. Такі рішення більш здійсненні і стійкі, тому що вони враховує потреби і інтереси всіх зацікавлених сторін, включаючи вразливі / маргіналізовані групи населення, i зацікавлені сторони краще розуміють результати і більше інвестують в них.

В результаті управлінські рішення, засновані на процесах участі громадськості, розглядаються як більш законні і менш схильні до оскарження. Особи, які приймають рішення, які повністю розуміють інтереси зацікавлених сторін, також стають кращими комунікаторами, здатними пояснювати рішення та їх обгрунтувати в термінах, зрозумілих зацікавленим сторонам, і способами, які пов'язані з цінностями і проблемами зацікавлених сторін.

Участь громадськості у процесах прийняття управлінських рішень розвиває потенціал спільноти, це $є$ ще одним важливим результатом постійної участі 
зацікавлених сторін у прийнятті рішень i їх реалізації. Це також $є$ розвиток здатності вирішувати складні соціальні проблеми[3]. Ця здатність включає поліпшення відносин i довіри між особами, що приймають рішення, i громадськістю, а також між самими зацікавленими сторонами. Крім того, якщо все зроблено правильно, участь громадськості допомагає навчити зацікавлені сторони осмисленим способам співробітництва та підходу один до одного, управління складними рішеннями i вирішення спорів. Зацікавлені сторони вчаться цінувати позиції один одного, спочатку дізнаючись про цінності i інтереси один одного.

Як тільки зацікавлені сторони запрошені в процес прийняття рішення, їм стає все важче просто стояти осторонь і говорити «ні». Як учасники ефективного процесу прийняття рішень, всі зацікавлені сторони повинні розуміти всі сторони проблеми, зважувати всі «за» і «проти» і приймати більш продумані рішення. Зацікавлені сторони і спільноти зазвичай не досягають цього самотужки. Органи публічної влади повинні усвідомлювати свою відповідальність за надання допомоги громадам в нарощуванні їх потенціалу для спільного вирішення проблем. Ця модель співтовариства сприяє співпраці для вирішення проблем практично у всіх сферах життя суспільства.

В основі кожного процесу участі громадськості лежить обіцянка, дана владою громадськості. Ця обіцянка представляє те, що громадськість може очікувати від органу публічної влади щодо доступу до потенційного впливу на вирішення проблеми. Обіцянка також визначає очікуваний рівень інформації і спілкування. Органи публічної влади, які дають чіткі i ясні обіцянки, встановлюють чітке розуміння процесу вирішення проблеми у всїх зацікавлених сторін i нести відповідальність. Без чітких обіцянок громадськість буде інтерпретувати широкий спектр очікувань, більшість 3 яких не призначені і не можуть бути виконані. Даючи обіцянки, важливо враховувати наступні три фактори[4, с.128]:

обіцяй тільки те, що, на твою думку, чи зможеш доставити

виконайте те, що обіцяли

продемонструйте те, що ви робите, ефективно спілкуючись.

Ефективна участь громадськості частково залежить від бажання і здатності органу публічної влади залучити громадськість до процесу прийняття рішень. Хоча вкрай важливо, щоб ОДВ розвинули навички обмірковування, планування та реалізації процесу участі громадськості, не менш важливо, щоб громадськість розвивала здатність ефективно брати участь в процесах прийняття рішень. Добре продуманий і щирий процес участі не зможе реалізувати свій потенціал, якщо у громадськості немає необхідних навичок участі. Отже, для державних органів важливо нарощувати потенціал участі громадськості.

Підвищення потенціалу участі може бути досягнуто кількома способами: моделювання поведінки, яке ви хочете бачити на протягом всього процесу; 
розробка i поширення серед громадськості керівних документів, що пропагують основні цінності участі громадськості та описують передовий досвід; навчання лідерів громад та представників зацікавлених сторін основоположним навичкам участі і комунікації з громадськістю;

особливу увагу i увагу до уразливих груп населення i маргіналізованих співтовариств;

виявлення лідерів-фасилітаторів в органах публічної влади для наставництва груп / лідерів спільнот шляхом партнерства 3 ними під час планування та реалізації процесів участі громадськості. Запрошення громадськості до участі в плануванні процесу може викликати у громадськості почуття причетності.

залучення професійних сторонніх фасилітаторів для інструктажу на початковому етапі проекту i зовнішніх зацікавлених сторін щодо розробки методів взаємодії.

по можливості, використання дорадчих незалежних форумів, які заохочують більш активні форми участі, замість вибору на користь громадських рад, які розглядаються органами публічної влади як більш «безпечні» і контрольовані.

надання інформаційної, методичної та технічної допомоги громадськості або суспільним групам, щоб допомогти їм зрозуміти технічну інформацію, що має відношення до ухваленого рішень.

Ці стратегії можуть допомогти підвищити здатність громадськості до ефективної участі. Однак постійний інтерес до участі громадськості буде залежати від того, в якій мірі процеси участі громадськості можуть призвести до можливості значного суспільного внеску та впливу на суспільно значущі проекти, а також від ступеня відповідальності оррганів публічної влади за ці результати.

Для успішної участі громадськості необхідні наступні умови:

реальна участь громадськості допомагає зміцнити здатність будь-якої спільноти конструктивно працювати разом і спільно вирішувати проблеми;

чітка мета і завдання - чітко визначена мета ролі громадськості у проекті, яка $\epsilon$ реальною, практичною і розділяється всіма зацікавленими сторонами. Органи публічної влади повинні визначити відповідний рівень або ступінь участі громадськості для прийняття рішення і відповідним чином встановити очікування громадськості. Ніхто не виграє, коли ОДВ обіцяють більше в плані участі громадськості, ніж вони готові взяти на себе і виконати. Фактично, обіцянки, які неможливо виконати, підірвуть довіру громадськості до процесу участі громадськості та в цілому до органів публічної влади;

чітка структура i процес - чітке визначення правил про те, як буде проводитися участь громадськості і як буде прийматися рішення;

фактична можливість впливу - реальна можливість для врахування громадської думки при прийнятті рішеннь;

прихильність процесу - державні службовці повинні бути готовими не тільки отримувати, але й враховувати думку громадськості при прийнятті управлінських рішень; 
інклюзивне і ефективне представництво - звернення до представників всіх зацікавлених сторін незалежно від раси, кольору шкіри, національного походження, сексуальної орієнтації або доходу.

Які додаткові фактори необхідно враховувати для успішної участі громадськості?

Прозорість являє собою готовність органів публічної влади в повній мірі ділитися інформацією, критеріями і обговореннями процесу прийняття рішень 3 громадськістю. Без прозорості громадська думка не буде гуртуватися на тих саме міркуваннях, які особи, які приймають рішення, фактично використовують при прийнятті рішень. В результаті навряд чи громадськість зрозуміє, чому приймаються рішення або як ці рішення вплинуть на їх життя. Дуже часто суспільне обурення викликано тим, що не була надана повна і своєчасна інформація або що ця інформація взагалі була виключена 3 процесу прийняття рішеньх[5].

Щоб забезпечити і підтримувати ефективну участь громадськості особи, які приймають рішення, повинні ретельно обміркувати, як вони підтримують цей процес. Деякі важливі елементи успішної участі громадськості можуть включати наступне:

достатні ресурси для проведення процесу - надати фінансування та персонал для підтримки всіх аспектів процесу, включаючи оцінку ситуації, інформаційнопропагандистську діяльність, а також моніторинг та врахування громадської думки, залучення вразливих груп населення;

здатність до участі співробітників і учасників - проведіть тренінг з навичок спілкування, інформаційно-роз'яснювальної роботи та спільного вирішення проблем;

атмосфера доброчесності та довіри до уряду і його авторитет важливі для участі громадськості. Участь громадськості не буде збільшуватися, якщо урядові установи або особи, які приймають рішення, корумповані або лукавлять щодо врахування громадської думки.

віра в цінність громадського вкладу - знання того, що громадський внесок призведе до більш ефективного прийняття рішень та що участь громадськості призведе до кращого управління;

здатність до залучення - забезпечення того, щоб органи публічної влади знали, як розробляти і реалізовувати процеси участі громадськості, і щоб ОДВ і громадськість в рівній мірі володіли знаннями і комунікативними навичками для ефективної участі в цьому процесі;

повна прозорість - своєчасний обмін зрозумілою і доступною інформацією для інформування громадськості про проблеми та можливості.

У демократичній державі забезпечення прозорості системи державного управління є однією з ключових, невід'ємних складових державної інформаційної політики, стратегічна мета якої полягає в побудові відкритого інформаційного суспільства. Як показує світовий досвід, проведення єдиної державної 
інформаційної політики, що включає постійний контроль інформаційної діяльності всіх інститутів і органів держави, вимагає координації 3 одного, наділеного належними директивними повноваженнями адміністративного центру на рівні вищого керівництва держави при персональній відповідальності за їі проведення одного з вищих державними посадовими осіб. Прикладом такого підходу може служити створення в 1980 році в Адміністративно-бюджетному управлінні США (Office of Management and Budget) Управління у справах інформаціï та регулювання (Office of Information and Regulatory Affairs), адміністратор (керівник) якого призначається Президентом США за порадою і за згодою Сенату Конгресу США і підзвітний Сенату і діяльність віце-президента США А.Гора (1993-2001)[6].

Висновки. Таким чином, участь громадськості слід розглядати як можливість прийняття ефективного публічно-управлінського рішення, яке вирішує проблеми 3 максимально можливим задоволенням i вигодою для зацікавлених сторін. Коли все зроблено правильно, час і зусилля, вкладені в участь громадськості, приносять дивіденди, оскільки призводять до прийняття більш прийнятного, здійсненного і стійкого управлінського рішення.

Перспективи подальших розвідок у даному напрямі автор бачить у розробки змісту та концептуальних основ процесі взаємодії структур сектору безпеки та оборони держави з громадськістю у контексті забезпечення національної безпеки.

\section{Лimepamypa:}

1. Ундір В. О. Принципи взаємодії органів державної влади і громадських структур як основа гармонізації суспільства URL: http://edu.lvivacademy.com/article/view/217606 DOI: https://doi.org/10.33990/2070-4011.64.2020.217606

2. Кармазіна О.О., Взаємодія органів публічного управління з громадськістю в контексті розвитку громадянського суспільства в Україні URL: http://webcache.googleusercontent.com/ search?q=cache:BaIXXZDhesQJ:academy.gov.ua/ej/ej17/PDF/30.pdf $+\& c d=1 \& h l=u k \& c t=c l n k \& g l=c z$

3. Ковбас I., Торончук I., Крайній П. Особливості взаємодії органів публічного врядування 3 консультативно-дорадчими органами. Адміністративне право i процес 4/2021. C.151-156. DOI https://doi.org/10.32849/2663-5313/2021.4.22

4. Ноєль-Нойман Э. Общественное мнение: Открытые спирали молчания. М. : ФАИР, 1996. $351 \mathrm{c}$.

5. Public Participation Guide: Introduction to Public Participation. URL: https://www.epa.gov/international-cooperation/public-participation-guide-introduction-public-participation

6. Public policies from a human rights perspective. Daniel Vázquez and Domitille Delaplace A Developing Field. URL: https://sur.conectas.org/en/public-policies-human-rights-perspective/

\section{References:}

1. Undir, V.O. (2020) Principi vzaєmodiï organiv derzhavnoï vladi i gromads'kih struktur jak osnova garmonizaciï suspil'stva [Principles of interaction between public authorities and public structures as a basis for harmonization of society]. Retrieved from: http://edu.lvivacademy.com/ article/view/217606 [in Ukrainian]

2. Karmazina, O.O. Vza€modija organiv publichnogo upravlinnja $\mathrm{z}$ gromads'kistju v konteksti rozvitku gromadjans'kogo suspil'stva v Ukraïni [Interaction of public administration bodies with the 
public in the context of civil society development in Ukraine] Retrieved from: http://webcache.googleusercontent.com/search?q=cache:BaIXXZDhesQJ:academy.gov.ua/ej/ej17 /PDF/ 30.pdf $+\& \mathrm{~cd}=1 \& \mathrm{hl}=\mathrm{en} \& \mathrm{ct}=\mathrm{clnk} \& \mathrm{gl}=\mathrm{cz}$ [in Ukrainian]

3. Kovbas, I., Toronchuk, I., Extreme, P. Osoblivosti vza€modiï organiv publichnogo vrjaduvannja z konsul'tativno-doradchimi organami [Features of interaction of public authorities with advisory bodies]. Administrative law and process - Administrativne pravo i process. 4/2021, 151-156 [in Ukrainian].

4. Noel-Neumann, E. (1996). Obshhestvennoe mnenie: Otkrytye spirali molchanija [Public opinion: Open spirals of silence]. Moscow: FAIR [in Russian].

5. Public Participation Guide: Introduction to Public Participation. URL: https://www.epa.gov/international-cooperation/public-participation-guide-introduction-publicparticipation

6. Public policies from a human rights perspective. Daniel Vázquez and Domitille Delaplace A Developing Field. URL: https://sur.conectas.org/en/public-policies-human-rights-perspective/ 